Melnyk Tetiana, Doctor of Sciences (Economics), Professor, Kyiv National University of Trade and Economics 19, Kyoto str., Kyiv, 02156, Ukraine ORCID: 0000-0002-3839-6018 Researcher ID: A-7616-2018

\title{
MODERN DEVELOPMENT OF INTERNATIONAL TRADE: NEOPROTECTIONISM AND THE TRADE WARS
}

The development of international trade at contemporary period can be characterized as a combination of neo-free-trading and neo-protectionism. The entire arsenal of trade and political struggle between countries against traditional forms of import restriction, effective measures for regulation of foreign trade having been taken administrative, financial, credit, technical and other features which make overwhelming obstacles that complicate free movement of goods across the borders of countries. Analysis and identification of current forms of national markets protection have shown that the expansion of protectionist forms and methods is the result of the application of non-tariff trade restrictions, which are actively used by industrialized (developed) countries, particularly in the United States, although they represent themselves as demonstrators of free trade. The consequences of confronting "great» economies are manifested in the form of trade wars, escalation of which can greatly affect global economy and trading as well as adversely influence upon the economies of developing countries.

Keywords: protectionism, neo-protectionism, international economic policy, trade wars, foreign trade.

Мельник Тетяна. Сучасний розвиток міжнародної торгівлі: неопротекціонізм і торговельні війни.

Розвиток міжнародної торгівлі на сучасному етапі можна характеризувати як поєднання неофрітрейдерства і неопротекиіонізму. В арсеналі торговельно-політичної боротьби країн поряд 3 традиційними формами обмеження імпорту набирають силу ефективні заходи регулювання зовнішньої торгівлі: адміністративні, фінансові, кредитні, технічні та інші, які в значній мірі ускладнюють вільне переміщення товарів крізь кордони держав. Аналіз та ідентифікація сучасних форм захисту національних ринків показав, що розширення протекиіоністських форм та методів здійснюється в 
результаті застосування нетарифних торговельних обмежень, які особливо активно використовуються індустріально розвиненими країнами, зокрема США, хоча самі вони є демонстративними прихильниками вільної торгівлі. Наслідки протистояння «великих» економік проявляється у вигляді «торговельних війн», ескалачія яких в значній мірі може вплинути на світову економіку і торгівлю та негативно позначитися на економіках країн, щу розвиваються.

Ключові слова: протекціонізм, неопротекціонізм, міжнародна економічна політика, «торговельна війна», зовнішня торгівля.

Relevance of research topic. Increasing openness of national economies and liberalization of the system of foreign economic relationship in general is being accompanied nowadays by a complex of contradictions between individual countries and groups of countries, international economic organizations, multinational corporations and banks. It is reflected in the evolution of foreign trade policy, which in the context of globalization can be defined as the ratio between neo-free-trading and neo-protectionism. Protectionism being traditionally implemented by customs tariff instruments to regulate foreign trade by restricting imports or fiscal policy to stimulate exports, and aimed primarily at achieving competitive positions of national producers, is more actively complemented by new instruments of stimulating discriminating and restrictive in nature, the purpose of which is to provide countries with new competitive advantages.

Formulation of the problem. When analyzing assessment of the globalization processes in the world trading system it should be admitted that the weakening of traditional barriers between countries has not yet seized trade conflicts and trade wars. Trade wars between states that protect their own manufacturers have been ever taken place. However, only by the end of the 20th century having had become an instrument for achieving geopolitical goals they got the status of special sharpness. According to leading foreign researchers, in the future, trade wars are become a major problem in relations between the main trading blocks [1], which necessitates further study of modern forms and features of their manifestation.

These problems are essential especially for Ukraine being the country which is currently solving the problem of effectively integrating into the system of modern world economic relationship. When taking a closer step by Ukraine on the way to entry into the international economic processes special attention should be paid to developing a strong mechanism of forming the relation between freedom of trade and protectionism, which would smoothen the consequences of the deterioration crisis of the world economic environment, while at the same time maximizing the benefits that can be obtained from the external sphere.

Analysis of recent researches and publications. Contemporary manifestations of the doctrine of protectionism in the genesis of international economic policy have 
been studied in the works of considerable number of foreign scholars, such as A. Åslund [1], F. Genereux [7], P. Krugman [9], A. Pozen [2], M. Roland [11] and others.

Ukrainian scientists, such as O. Dovgal [18], A. Mazaraki [25], L. Polishchuk [23], V. Sidenko [19] and others investigated manifestations of protectionism within trade policy based on the introduction of tariff restrictions and, later, non-tariff protection measures. In the works of such domestic researchers as O. Bulatova [17], V. Panchenko [21, 22], N. Reznikova [21, 22], I. Puzanov [24], etc. protectionism is considered as a complex of intricate mechanism of economic policy aimed at raising competitiveness within national economy.

Giving the tribute to domestic researchers' workouts, current global trends of protectionism in free trade, the consequences of the introduction of safeguards for developed and developing countries, the ability to protect economic interests of national manufacturers in the conditions of neo-protectionism require in-depth scientific research.

Presenting main material. Global economic instability is the challenge that gives rise to countries' striving of taking up protectionist measures to stabilize national economies. Developed countries, demanding to follow the principles of liberalism, protect their own market taking up measures that actually contradict the declared goals of the globalized economy, because they impose high customs duties unachievable for the rest of the world national economies, technical requirements, government subsidies for agricultural producers and other industries, whose activities are part of ensuring a high level of national security.

All these transformations in the world economy, the expansion of protectionist measures, the differentiated nature of protection methods of the national economy allow to confirm the formation of a new direction in economic theory - neoprotectionism.

Neo-protectionism is the policy of establishing administrative, financial, creditproviding, technical and other barriers that significantly impede free movement of goods across the country borders. The main instruments of neo-protectionism are tariff quotas, phytosanitary norms, state subsidies, technical barriers, countervailing duties, anti-dumping measures, standardization and certification of products, voluntary export restrictions, export crediting, etc. At the same time these instruments are not direct and open measures, therefore, on the one hand, they do not contradict foreign policy interests of the government, and on the other hand, they are effective measures to protect national exporter. Consequently, the main feature of neo-protectionism is furtiveness.

For example, voluntary export restriction is an arrangement between the exporting and importing country, under which the exporting country restricts the export of certain goods, but initiated by the importing country. This arrangement is not voluntary; it is merely a disguised coercion of trading partners to commit themselves 
to restrict the export of certain goods to a particular country in order to avoid more serious protection measures. Usually they are used in their foreign economic policy by countries such as the USA and Western European countries; i. e. developed countries are actually forced to shift responsibility mostly on to developing countries as well as transmitting quite negative consequences along with it.

Thus, although both countries are supposed to have negative effects on the balance of current operations, the importing country will still have certain advantages, because of imports decrease, national production increases on either. Applying such a policy, the importing country protects the products of those industries that are in crisis or in the case of sharp increase of goods supply from particular countries and significant increase in their share within the total volume. Thus, the importing country protects its domestic market by building trade barriers that are imposed at the border of the exporting country.

WTO and international research center analysts are constantly monitoring and estimating trade measures taken by countries around the world. The results of such monitoring show that even against the backdrop of the gradual recovery of national economies after the global economic crisis of 2009 (Table 1), the tendency to apply protectionist measures not just diminish but, on the contrary, they've been increasing. The number of protectionist measures in 2015 exceeded even the level of 2009 crisis [3].

In $201849 \%$ of the world trade came under protectionist measures. In the same year governments of the world made 1870 interventions into global trade, incl. 1707 safeguard measures and 400 forms of activity directed onto liberalization. Subsidies for consumer/producer support, export incentives and tariff barriers were the most commonly spread in the past year. At the same time, as we can observe (Table 1), in recent years there has been a steady increase, along with the reduction of the number of tariff barriers.

Developed and fast-growing countries actively protect national manufacturers. In particular, the G20 has introduced 1,271 new protectionist acts and 327 trade liberalization measures in 2018 [15]. According to Global Trade Alert [8], more than $50 \%$ of the safeguards have been implemented by 10 countries: Canada, USA, Germany, India, Argentina, Brazil, Italy, United Kingdom, China, and Australia.

Table 1

Dynamics of world GDP, exports, imports and measures for protectionism

\begin{tabular}{|l|r|r|r|r|r|r|}
\hline & \multicolumn{1}{|c|}{2009} & \multicolumn{1}{|c|}{2012} & 2015 & 2016 & 2017 & 2018 \\
\hline \multicolumn{1}{|c|}{ GDP, growth rate, \% } \\
\hline World & $-0,1$ & 3,5 & 3,4 & 3,4 & 3,8 & 3,6 \\
\hline Developed countries & $-3,4$ & 1,2 & 1,9 & 1,7 & 2,4 & 2,2 \\
\hline Developing countries & 2,8 & 5,4 & 4,3 & 4,6 & 4,8 & 4,5 \\
\hline
\end{tabular}




\begin{tabular}{|c|c|c|c|c|c|c|}
\hline & 2009 & 2012 & 2015 & 2016 & 2017 & 2018 \\
\hline \multicolumn{7}{|c|}{ International trade, growth rate, \% } \\
\hline Volumes of world trade & $-10,5$ & 2,8 & 2,8 & 2,2 & 5,4 & 3,8 \\
\hline \multicolumn{7}{|c|}{ Exports of goods and services, growth rate, \% } \\
\hline World & $-10,1$ & 3,1 & 2,9 & 2,2 & 5,4 & 3,5 \\
\hline Developed countries & $-11,2$ & 2,3 & 3,8 & 2,2 & 4,4 & 3,1 \\
\hline Developing countries & $-8,2$ & 4,0 & 1,8 & 2,5 & 7,2 & 4,3 \\
\hline \multicolumn{7}{|c|}{ Imports of goods and services, growth rate, \% } \\
\hline World & $-10,9$ & 2,9 & 2,7 & 2,3 & 5,4 & 4,1 \\
\hline Developed countries & $-11,6$ & 1,2 & 4,6 & 2,7 & 4,3 & 3,3 \\
\hline Developing countries & $-9,3$ & 5,2 & $-0,9$ & 2,0 & 7,5 & 5,6 \\
\hline $\begin{array}{l}\text { The number of protectionist } \\
\text { measures in the world, total, units }\end{array}$ & 1332 & 1466 & 1376 & 1238 & 1483 & 1707 \\
\hline \multicolumn{7}{|l|}{ Including: } \\
\hline $\begin{array}{l}\text { Subsidies (excluding export } \\
\text { subsidies), units }\end{array}$ & 344 & 346 & 402 & 405 & 550 & 744 \\
\hline Share of subsidies, $\%$ & 25,8 & 23,6 & 29,2 & 32,7 & 37,1 & 43,6 \\
\hline $\begin{array}{l}\text { Export-related measures (including } \\
\text { export subsidies), units }\end{array}$ & 322 & 362 & 329 & 274 & 354 & 319 \\
\hline Share of export-related activities, $\%$ & 24,2 & 24,7 & 23,9 & 22,1 & 23,9 & 18,7 \\
\hline Tariff barriers, units & 230 & 263 & 246 & 200 & 210 & 198 \\
\hline Share of tariff barriers, $\%$ & 17,3 & 17,9 & 17,9 & 16,2 & 14,2 & 11,6 \\
\hline $\begin{array}{l}\text { Conditional trade defense measures, } \\
\text { units }\end{array}$ & 206 & 205 & 138 & 143 & 164 & 174 \\
\hline Specific share & 15,5 & 14 & 10 & 11,6 & 11,1 & 10,2 \\
\hline $\begin{array}{l}\text { Restrictions on public procurement, } \\
\text { units }\end{array}$ & 79 & 66 & 62 & 64 & 70 & 103 \\
\hline $\begin{array}{l}\text { Share of public procurement } \\
\text { restriction, \% }\end{array}$ & 5,9 & 4,5 & 4,5 & 5,2 & 4,7 & 6,0 \\
\hline Other, units & 151 & 224 & 199 & 152 & 135 & 169 \\
\hline Other measures share, $\%$ & 11,3 & 15,3 & 14,5 & 12,3 & 9,1 & 9,9 \\
\hline
\end{tabular}

Source: calculated by author based on data [7, 15]

The beginning of Donald Trump's administration working in US in January 2017 was marked by surge protectionism, designed to stimulate job positions initiations and foreign direct investment (FDI) through high tariffs on imported goods and reduced taxes on exported goods. US protectionism based on the principles of mercantilism and active trade balance, views world trade as a field of winners and losers [20]. As a result, the US government criticizes China, Japan, the Republic of Korea, and all free trade agreements, such as NAFTA and free trade agreements (FTA) between Korea and the United States. Relying on a simplified analytical framework, US President D. Trump has ordered to withdraw from the Trans-Pacific Partnership and has made statements on the review of NAFTA and FTA with Korea, which are currently being under discussion. According to the new approaches of the President, 
the US government is considering penalty tariffs against China and at the same time encouraging US companies to reconsider their approaches to investing abroad. Thus, the US government demonstrates its intention to overestimate the role of the US in the global economic and geopolitical order [4, 7, 13].

Major prerequisite for US protectionist economic measures is a sustained negative foreign trade balance within international trade of the country. The contradictions with China have arisen amid rapid changes, first of all, in economic relations. Thus, in 2017, the US trade deficit with China amounted to $\$ 375$ billion. Contradictions with Europe have arisen amid the close ties of some European countries with Russia, which the USA attributes to countries that deliver threat to national security. The United States, by imposing duties, hopes to force some EU countries to reduce co-operation with Russia and make Russia more compliant.

According to the WTO data, as of 2019, the United States is the country with the greatest number of protectionist measures against trading partners and subject to a set of similar actions [16]. In February of the current year, WTO officials issued information that global trade growth in goods would constantly slowly go down to $3.7 \%$ in 2019 due to protectionist measures applied.

Nevertheless, according to the analysis [14], despite high-profile protectionism, the USA has one of the lowest import tariffs among the most developed countries in the world. The average US import tariff in 2017 was 3.5\% (the highest one was in South Korea $-13.9 \%$, Argentina -13.7 and Brazil $-13.5 \%$ ); the lowest was fixated in Australia (2.5\%). The country mainly applies non-tariff measures.

Based upon the analysis of data provided by the WTO showing the frequency of non-tariff barriers implementation (sanitary and phytosanitary measures, technical barriers, antidumping, countervailing measures, safeguards, special safeguards, quantitative restrictions, quotas) and export subsidies, we may point out that the integration structure was manifested as the least protectionist in the EU-USA-China triad. By the end of 2016 the European authorities supported or implemented 1931 non-tariff measures in total, most of which consisted of technical barriers, namely 1047, sanitary and phytosanitary barriers (591).

On the contrary, the USA has imposed itself as the most protectionist trade entity, considering that 5058 non-tariff barriers have been implemented, which exceeds the number registered in the EU in 2.6 times. Most trade barriers consisted of sanitary and phytosanitary barriers (2913) and technical barriers (1455). China ranks second place in the implementation of non-protectionist measures with 2530 non-tariff measures at the end of 2016 [14]. Taking into account the data analyzed, it can be affirmed that while the EU continues continue to implement non-tariff measures that affect free trade with the countries of the third world, it (EU) cannot be considered as the promoter of this trend. 
Consequences of the introduction of protectionist measures for business and economy of the country as a whole is an important current issue. According to a survey of more than 2,000 business owners conducted by Global Innovation Barometer in 2018 [6] about the positive effects of government protectionist measures on business, there is the conclusion that business is divided into two camps; and «disputes» about protectionism and free trade are just gaining speed of momentum. For example, in France and Great Britain two-thirds of business owners approve protectionist measures, while in Germany they are much smaller in number, and in the United States there are just half of them.

Summarizing the research findings, it can be noted that protectionism in its short term perspective, especially for developing countries, can become a tool for the national manufacturer developing and stimulating instrument for domestic demand by temporarily protecting new industries and new products for the world market; maintaining competition on domestic market; significant investment into education (industrial policy stimulates demand for education); active cooperation between manufacturers and local suppliers; the spreading of technology to maximize the amount of knowledge bulk transmitted.

However, according to the IMF assessment, protectionist policies are the cause of trade wars and can lead to a recession in the global economy. The introduction of tariff and non-tariff barriers hinders the development of industrial cooperation and technology exchange. The closed market does not stimulate competition, resulting in poor quality and slower innovation [10]. Some studies show that in the medium-term perspective protectionism leads to decline in domestic manufacture, productivity and investment. It should be borne in mind that the introduction of protectionism can cause a counterthrust from countries on the world [9].

According to experts' opinion, the effects of the «great confrontation» would be laid upon and felt up by the weaker countries, to which Ukraine belongs. In particular, one can expect manifestations in: - reduction of the inflow of foreign direct investment into the country, which already have negligible volumes; - undermining stability of the world financial system as a result of the China-US trade war, which will also primarily affect the financial systems of underdeveloped countries; - due to the «loosening» of the situation on the commodity markets and because of the confrontation between the USA and China, in case of another crisis, the collapse is supposed to take place on commodity markets, which will negatively influence the Ukrainian economy, since about $70 \%$ of domestic exports is the raw materials [19].

As A. Aslund notes, large Ukrainian companies are exporting steel and agricultural products, and these export destinations are to be greatly affected by the trade war [1]. Therefore, in his opinion, Ukraine should be extremely interested in open markets. 
The number of measures taken by the countries of the world against the Ukrainian manufacturer and currently in force today equals to 1176 units. These norms apply to: metallurgy (products of ferrous metals and steel - 244); ferrous metals and steel (110); automotive equipment (122); mechanical engineering (agricultural machinery - 96); agriculture (grains - 93). The largest number of such measures is implemented by the Russian Federation - 247.

According to the Global Trade Alert [8], the share of exports subject to protectionist measures introduced by both Ukraine and importing countries and third countries of the world is increasing annually.

In 2017 , on average $45 \%$ of Ukraine's exports and $27 \%$ of imports fell under the instruments of protectionism. Most measures are taken against Ukrainian exports by the third parties and importers - non-tariff regulatory methods and import duties.

In Ukraine, the protection of the national producer is mainly due to the antidumping and import duties. At the same time, the main instruments in the developed countries are financial support of the producer through subsidies, state support in foreign markets, preferential export credits, and financial grants.

Therefore, in the short term perspective, some protectionist policy instruments such as state financial support for research and development, export credit policy, export insurance, investment protection, privileges and investment preferences may be used to import, replace, increase domestic production and resume domestic manufacture; production and export of high-tech products (innovations), state promotion of entering the world markets through diplomatic missions, trade missions (tools of promotion). Urgent measures protecting Ukrainian manufacturer from unfair imports may include: anti-dumping and countervailing duties, temporary restriction of imports to protect domestic industries.

Conclusion. Main characteristic features of the contemporary period of world economy and trade development, in particular, are the tendencies of disintegration and protectionism. When estimating modern protectionism, experts call it neoprotectionism, although combinations of security instruments are traditional customs tariffs, state support, subsidies, tender policy, product standardization and certification.

Domestic manufacturers are actively protected by developed and fast-growing countries, in particular the United States has the highest number of protectionist measures, mostly non-tariff, against trading partners, and against which a set of similar actions is applied. There are also non-tariff measures in the EU, most of which are technical, sanitary and phytosanitary barriers.

There are differing views on the implications of protectionist measures for national business. In France and Great Britain two-thirds of business owners approve protectionist measures, while in Germany there are far fewer and half of them are in the United States. 
Short-term perspective protectionism, especially applied in developing countries, can become a tool for developing national manufacturer and stimulating domestic demand by: temporarily protecting new industries and new products for the world market; maintaining competition on domestic market; significant investment into education (industrial policy stimulates demand for education); active cooperation between manufacturers and local suppliers; spreading technology to maximize the amount of knowledge transmitted. However, the medium-term perspective protectionism leads to decline in domestic manufacture, productivity and investment.

Trade wars among developed countries can have adverse effects on underdeveloped countries, such as Ukraine, which may be manifested through decline of foreign investment and commodities exports, and instability of the monetary and financial system.

The effectiveness of neo-protectionism in Ukrainian realities should be manifested, on one hand, in the protection of national economic interests in foreign markets by state assistance of the whole world markets through diplomatic missions, trade missions (promotion tool), and on the other hand, along with the implementation of national manufacturer protection measures, which among others may be in the short term perspective, they are government financial support for research and development, export credit policy, export insurance, investment protection, benefits and preferences for investments in production and export of high-tech products (innovation).

\section{REFERENCES}

1. Åslund A., Dąbrowski M. (2015) Challenges of Globalization: Imbalances and Growth. Retrieved from https://www.researchgate.net/publication/227441550 [in English]

2. Adam S. Posen (2018) The Post-American World Economy. Globalization in the Trump Era. Retrieved from https://www.foreignaffairs.com/articles/unitedstates/2018-02-13/post-american world-economy. [in English]

3. Evenett S.J., Fritz J. Global Trade Plateaus: The $19^{\text {th }}$ Global Trade Alert Report. London: Centre for Economic Policy Research, 2016, 120 p. [in English]

4. Feinman J. N. (2016) A Closer Look: Backlash against Globalization: Deja vu? Deutsch Asset Management. Retrieved from https://fundsus.deutscheam.com/ EN/docs/research/A_Closer_Look_by_Josh_Feinman-2016-12.pdf. [in English]

5. Free Trade Agreement. Retrieved from https:/ustr.gov/about-us/policyoffices/press-office/press-releases/2017/july/ustr-calls-special-session-under-us [in English]

6. Genereux F. (2017) Protectionism: A Brake on Economic Growth. Retrieved from https://www.desjardins.com/ressources/pdf/pv170217-e.pdf. [in English] 
7. Global Dynamics. The Global Trade Alert. Retrieved from https://www.globaltradealert.org/global_dynamics/area_all/year-from_2018/year-to_2018 [in English]

8. Krugman P. (2018) Thinking About a Trade War. Retrieved from https://www.nytimes.com/2018/06/17/opinion/thinking-about-a-trade-war-verywonkish.html [in English]

9. Macroeconomic Consequences of Tariffs. IMF. Retrieved from https://www.imf.org/en/Publications/WP/Issues/2019/01/15/MacroeconomicConsequences-of-Tariffs-46469 [in English]

10. Noland M., Robinson S., Moran T. (2016) Impact of Clinton's and Trump's Trade Proposals / M. Noland, G. C. Hufbauer, S. Robinson, T. Moran (eds). Assessing Trade Agendas in the US Presidential Campaign, Peterson Institute for International Economics (PIIE) Briefing, 16-6, P. 17-39 [in English]

11. Report on G20 Trade Measures (Mid-October 2017 To Mid-May 2018). Retrieved from https://www.wto.org/english/news_e/news18_e/g20_wto_report_july 18_e.pdf [in English]

12. United States Trade Representative. USTR Calls a Special Session Under the U.S. Korea Free Trade Agreement. July. Retrieved from https://ustr.gov/aboutus/policy-offices/press-office/press-releases/2017/july/ustr-calls-special-session-underus [in English]

13. World Tariff Profiles 2017 Retrieved from https://www.wto.org/english/ res_e/publications_e/world_tariff_profiles19_e.htm [in English]

14. World Tariff Profiles 2018. Retrieved from https://www.wto.org/english/ res_e/publications_e/world_tariff_profiles19_e.htm [in English]

15. World Trade Statistical Review 2017. Retrieved from https://www.wto.org/ english/res_e/statis_e/wts2017_e/wts2017_e.pdf [in English]

16. Bulatova O. V., Marena T.V. (2018) Osoblyvosti vykorystannia protektsionistskykh zakhodiv $\mathrm{v}$ umovakh vilnoi torhivli [Features of the use of protectionist measures in the conditions of free trade], Mizhnarodni vidnosyny Seriia «Ekonomichni nauky» [International Relations. Series. «Economic Sciences»], Vol.16, P. 65-68. [in Ukrainian]

17. Dovgal O. A. (2004) Dialektyka protektsionizmu i liberalizmu u zovnishn'oekonomichnij politytsi [Dialectics of protectionism and liberalism in foreign economic policy], Ekonomika rozvytku [Economics of Development], Vol. 4 (32), P. 31-35. [in Ukrainian]

18. Michkovskaya N. (2018) Eho torgovyih voyn: kak mirovyie problemyi otrazhayutsya na Ukraine [Echo of trade wars: how world problems are reflected in Ukraine], Retrieved from https://kp.ua/economics/607633-ekho-torhovykh-voin-kakmyrovye-problemy-otrazhauitsia-na-ukrayne [in Russian] 
19. Park S. C. (2018) US protectionism and the violation of the trade balance between the US and the countries of Northeast Asia, International Organizations Research Journal, Vol. 13(2), P. 86 -114. [in English]

20. Panchenko V., Reznikova N. (2017) Vid protektsionizmu do neoprotektsionizmu: novi vymiry liberalnoho rehuliuvannia [From protectionism to neo-protectionism: new dimensions of liberal regulation], Mizhnarodna ekonomichna polityka [The International Economic Policy], Vol. 2(27), P. 95 - 117. [in Ukrainian]

21. Panchenko V., Reznikova N. (2014) Nova norma svitovoi ekonomiky yak seredovyshche stanovlennia neoprotektsionizmu [The New Norm of the World Economy as the Environment of Neoprotectionism], Mizhnarodni vidnosyny Seriia «Ekonomichni nauky» [International Relations. Series. «Economic Sciences»],Vol. 4. Retrieved from http://journals.iir.kiev.ua/index.php/ec_n/article/view/3398/3073 [in Ukrainian]

22. Polishchuk L. S. (2018) Suchasni instrumenty protektsionizmu osnovnykh tsentriv svitovoho hospodarstva [Modern instruments of protectionism of major centers of the world economy], Mizhnarodni vidnosyny Seriia «Ekonomichni nauky» [International Relations. Series. «Economic Sciences»], Vol. 16, P. 46-49. [in Ukrainian]

23. Puzanov I. (2018) Praktyka protektsionizmu v suchasnykh umovakh [The practice of protectionism in modern conditions], Mizhnarodni vidnosyny Seriia «Ekonomichni nauky» [International Relations. Series. «Economic Sciences»], Vol. 16, P. 16-20. [in Ukrainian]

24. Mazaraki A., Melnyk T., Yukhimenko V. and others (2014) Stratehiia postkryzovoho rozvytku zovnishnoekonomichnoho sektora Ukrainy [Strategy of the post-crisis development of the foreign economic sector of Ukraine], Kyiv: KNUTE, 652 p. [in Ukrainian] 